\title{
Latex Allergy and Occupational Exposure: The Patient's Perspective
}

Baiardini $\mathrm{I}^{1}$, Di Leo $\mathrm{E}^{2}$, Molinengo $\mathrm{G}^{3}$, Braido $\mathrm{F}^{4}$, Canonica $\mathrm{GW}^{1,5}$, Nettis $\mathrm{E}^{6}$

${ }^{1}$ Department of Biomedical Sciences, Humanitas University, Milan, Italy

${ }^{2}$ Section of Allergy and Clinical Immunology, Unitof Internal Medicine "F. Miulli" Hospital, Acquaviva delle Fonti, Bari, Italy ${ }^{3}$ Department of Psychology, University of Turin, Turin, Italy

${ }^{4}$ Department of Internal Medicine, IRCCS San Martino di Genova University Hospital, Genoa, Italy

${ }^{5}$ Personalized Medicine, Asthma and Allergy Clinic, Humanitas Research Hospital, Milano, Italy

${ }^{6}$ Department of Biomedical Sciences and Human Oncology Unit of Internal Medicine "G. Baccelli" 8, "Aldo Moro" University of Bari Medical School, Policlinico, Bari, Italy

J Investig Allergol Clin Immunol 2018; Vol. 28(4): 269-271 doi: 10.18176/jiaci.0257

Key words: Latex allergy. Health-related quality of life. Well-being. Illness perception. Coping strategies.

Palabras clave: Alergia a látex. Calidad de vida relacionada con la salud. Bienestar. Percepción de enfermedad. Estrategias de afrontamiento.

Natural rubber latex (NRL) allergy affects $0.3 \%$ to $1 \%$ of the general population [1], and its prevalence is higher among health care workers (range, 2.8\%-17\%) [2,3].

In sensitized patients, exposure to NRL proteins can provoke a type I IgE-mediated hypersensitivity reaction involving various organs and systems and a type IV reaction responsible for contact dermatitis [2,3]. Clinical manifestations, which occur within a few minutes after contact with NRL proteins, include urticaria, angioedema, conjunctivitis, allergic rhinitis, asthma, and anaphylaxis [4].

Unlike other allergic diseases, where patient-reported outcomes (PROs) are increasingly investigated, few data are available on the impact of latex allergy on the patient's experience.

Nienhaus et al [5] explored the effect of specific interventions for patients with occupational allergy and found that, when contact with NRL is avoided, health-related quality of life (HRQOL) and work activity improve.

Similar results were found by Power et al [6], who detected an improvement in HRQOL in 39 health care workers with latex allergy after avoidance of latex exposure.

Lewis-Jones et al $[7,8]$ developed a specific HRQOL questionnaire for latex allergy and showed that this condition has a profound effect on both patients and caregivers. The tool was also validated in Spanish, although it has not yet been used to explore HRQOL in these patients [1].

The aim of our study was to add to current knowledge about patients' experience of latex allergy resulting from occupational exposure. In particular, we were interested in testing the following: 
Table. Comparison of Psychological General Well-Being Index Scores of Patients With and Without Occupational Allergy and an Italian Normative Sample

\begin{tabular}{|c|c|c|c|c|c|}
\hline & & Mean (SD) & $\begin{array}{c}\text { Mean (SD), } \\
\text { Normative Sample }\end{array}$ & $t(d f)$ & $P$ Value \\
\hline Anxiety & $\begin{array}{l}\text { Occupational latex allergy } \\
\text { Nonoccupational latex allergy }\end{array}$ & $\begin{array}{r}15.32(5.17) \\
15.63(5.47)\end{array}$ & $17.30(4.96)$ & $\begin{array}{l}-2.16 \\
-2.03\end{array}$ & $\begin{array}{l}.04 \\
.048\end{array}$ \\
\hline Depressed mood & $\begin{array}{l}\text { Occupational latex allergy } \\
\text { Nonoccupational latex allergy }\end{array}$ & $\begin{array}{l}11.50(2.56) \\
11.46(2.86)\end{array}$ & $12.40(2.62)$ & $\begin{array}{l}-2.16 \\
-2.49\end{array}$ & $\begin{array}{l}.037 \\
.016\end{array}$ \\
\hline Positive well-being & $\begin{array}{l}\text { Occupational latex allergy } \\
\text { Nonoccupational latex allergy }\end{array}$ & $\begin{array}{l}10.74(3.44) \\
11.02(3.96)\end{array}$ & $11.80(4.02)$ & $\begin{array}{l}-2.08 \\
-1.68\end{array}$ & $\begin{array}{l}.044 \\
.98\end{array}$ \\
\hline Self-control & $\begin{array}{l}\text { Occupational latex allergy } \\
\text { Nonoccupational latex allergy }\end{array}$ & $\begin{array}{l}11.10(2.78) \\
11.42(2.72)\end{array}$ & $11.80(2.69)$ & $\begin{array}{l}-2.21 \\
-1.88\end{array}$ & $\begin{array}{l}.034 \\
.065\end{array}$ \\
\hline General Health & $\begin{array}{l}\text { Occupational latex allergy } \\
\text { Nonoccupational latex allergy }\end{array}$ & $\begin{array}{l}10.05(2.52) \\
10.26(2.58)\end{array}$ & $11.10(3.07)$ & $\begin{array}{l}-3.53 \\
-3.61\end{array}$ & $\begin{array}{l}.001 \\
.001\end{array}$ \\
\hline Vitality & $\begin{array}{l}\text { Occupational latex allergy } \\
\text { Nonoccupational latex allergy }\end{array}$ & $\begin{array}{l}12.21(3.01) \\
11.95(4.18)\end{array}$ & $13.40(4.00)$ & $\begin{array}{l}-3.26 \\
-3.35\end{array}$ & $\begin{array}{l}.002 \\
.002\end{array}$ \\
\hline
\end{tabular}

- Whether patients with occupational latex allergy differ from those with nonoccupational allergy in terms of HRQOL, well-being, perception of illness, and coping strategies.

- Whether the well-being of patients with occupational or nonoccupational latex allergy is different from that of the general population.

This cross-sectional, observational study was performed on a population of patients aged $\geq 18$ years diagnosed with latex allergy between 2014 and 2016. Patients experienced an immediate reaction after latex exposure and reported a positive result in a skin prick test and/or serum sIgE determination against latex.

The study consisted of the self-completion of PRO instruments after the clinical assessment at a single visit.

Once written informed consent was obtained, patients were invited to complete a specific questionnaire to assess HRQOL, namely, the Dermatology Life Quality Index (DLQI) [9] and other instruments widely used to assess PROs in allergic diseases (10): Psychological General Well-Being Index (PGWBI), Illness Perception Questionnaire (IPQ-R), and Coping Orientations to Problem Experienced (COPE).

A descriptive analysis was performed. One-sample and 2 -sample $t$ tests were used to compare means. Analyses were performed using IBM SPSS version 20.0.

A total of 115 eligible patients were invited to participate; 15 refused and 100 completed the questionnaires. Five patients were excluded owing to missing data about their job. A total of 95 patients (79 women, mean age 40.03 [10.31]) were considered for analysis. In 38 patients, latex allergy was related to work.

The burden of disease in HRQOL was relevant in both groups: patients with nonoccupational latex allergy had significantly higher scores in DLQI than those with occupational latex allergy (18.13 vs $20.21, P=.027)$. No significant differences were found between the 2 groups in terms of psychological well-being, perception of illness, and coping strategies. The Table shows the comparison of PGWBI scores for patients with and without occupational allergy and an Italian normative sample.
Our study was carried out in a large sample of patients diagnosed with latex allergy and referred by their allergists. The mean DLQI scores of both groups indicate that skin problems due to latex allergy have a marked effect on patients' HRQOL. Our data confirm the results of a previous study in health care workers [5]. Interestingly, the impact on HRQOL was higher in patients with nonoccupational latex allergy, suggesting that, from a subjective viewpoint, the consequences of disease go beyond the workplace. It is possible to hypothesize that, whereas procedures and protocols are available for health professionals and workers, it is difficult to prevent contact with latex in daily life.

Apart from HRQOL, the patient's perspective about latex does not differ between individuals with and without occupational exposure. The use of validated PROs has shown how the impact of disease on psychological well-being, the perception of illness, and the strategies that the patient uses to deal with it, are similar in both groups. These results suggest that the subjective component should be carefully evaluated in all patients, and not only in those with an occupational disease.

The use of a generic measure (PGWBI) enabled us to detect how patients' general psychological well-being is affected. When compared with the reference sample, both patients with occupational and nonoccupational latex allergy show a significantly higher level of anxiety and depression and significantly lower scores in positive well-being. The presence of the disease seems to interfere with all the dimensions of the patient's mood, thus increasing his/her distress. Moreover, patients with occupational allergy report a significant reduction in their level of self-control, probably due to the difficulties and changes they experience in their professional activity.

Our results should be interpreted with caution, given that our study was conducted in a single center with a limited number of patients and its cross-sectional nature does not enable us to draw causal inferences.

In conclusion, our study highlights how latex allergy interferes with HRQOL and significantly reduces well-being compared with a reference sample. Compared with patients with nonoccupational allergy, those with occupational allergy had a better HRQOL and similar scores in well-being, 
perception of illness, and coping. However, their level of selfcontrol was significantly lower than in the reference sample.

The evaluation of the individual perspective can provide useful information for designing individualized management plans for better care of patients with latex allergy.

\section{Funding}

The authors declare that no funding was received for this study.

\section{Conflicts of Interest}

The authors declare that they have no conflicts of interest.

\section{References}

1. Diéguez MC, Cerecedo I, Muriel A, Losada A, García E, Lázaro $\mathrm{M}$, de la Hoz B. Adaptation and validation of the Spanish version of the Quality Of Life in Latex Allergy questionnaire (QOLLA). J Investig Allergol Clin Immunol. 2011;21:283-9.

2. Nettis E,Assennato G, Ferrannini A, Tursi A. Type I allergy to natural rubber latex and type IV allergy to rubber chemicals in health care workers with glove-related skin symptoms. Clin Exp Allergy. 2002;32:441-7.

3. Holguín-Gómez L, Sastre Domínguez J. Occupational Contact Dermatitis in Spain. J Invest Allergol Clin Immunol. 2017;27:134-6.

4. Turjanmaa K. Incidence of immediate allergy to latex gloves in hospital personnel. Contact Dermatitis. 1987;17:270-5.

5. Nienhaus A, Kromark K, Raulf-Heimsoth M, van Kampen V, Merget R. Outcome of occupational latex allergy--work ability and quality of life. PLoS One. 2008;3:e3459.

6. Power S, Gallagher J, Meaney S. Quality of life in health care workers with latex allergy. Occup Med (Lond). 2010;60:62-5.

7. Lewis-Jones MS, Dawe RS, Lowe JG. Quality of life of patients with type 1 latex allergy: use and primary validation of the QoLLA questionnaire. Abstracts for the British Association of Dermatologists 85th Annual Meeting, Glasgow, United Kingdom, 5-8 July 2005. Br J Dermatol. 2005;153 (Suppl. 1):1-98.

8. Lewis-Jones MS, Dawe RS, Lowe JG. Quality of life of children with type 1 latex allergy and their parents: use and primary validation of the QoLLA-C and QoLLA-P questionnaires. Br J Dermatol. 2005;153 (Suppl. 1):83-4.

9. Finlay AY, Khan GK. Dermatology Life Quality Index (DLQI)-a simple practical measure for routine clinical use. Clin Exp Dermatol. 1994;19:210-6.

10. Braido F, Bousquet PJ, Brzoza Z, Canonica GW, Compalati $E$, Fiocchi $A$, et al. Specific recommendations for PROs and HRQoL assessment in allergic rhinitis and/or asthma: a GA(2) LEN taskforce position paper. Allergy. 2010;65:959-68.

Manuscript received February 16, 2018; accepted for publication March 26, 2018.

Giorgia Molinengo

Department of Psychology

University of Turin

Via Verdi, 10

10124 Turin, Italy

E-mail: giorgia.molinengo@unito.it 